\title{
The Effectiveness of Marriage Age Limit Regulations
}

\section{Chamidah*) And Akhmad Khisni**)}

*) Civil Servant of the Religious Court of Jepara, E-mail: mydha77@yahoo.com

${ }^{* *}$ Faculty of Law, Universitas Islam Sultan Agung (UNISSULA) Semarang

\begin{abstract}
.
This research aims to know the effectiveness of the regulation on the marriage age limit based on Act No. 16 of 2019. The research method used is the juridicalsociological research method, The juridical approach will discuss research using laws relating to the regulation of the marriage age limit and marriage dispensation contained in Act No. 1 of 1974, Constitution Number 16 of 2019, the Compilation of Islamic Law, and others, while a sociological approach is used to find out and analyze the judge's view of the case for a marriage dispensation application. The results of the study concluded that the regulation of the minimum age limit for women to marry was raised in Act No. 16 of 2019 was not effective for the people of Jepara Regency, the increase in applications for marriage dispensation at the Jepara Religious Court experienced a very significant increase, as indicated by the number of applications for marriage dispensation experienced a very significant increase, 2 times more than before the birth of Act No. 16 of 2019.
\end{abstract}

Keywords: Age; Effectiveness; Limit; Marriage; Regulation.

\section{Introduction}

Child marriage is a very complex issue, it is not enough to just look at it from one point of view, there are basic and basic things that must be considered in child marriage, namely those relating to the safety of the child's soul, the continuity of children's education and the safety of offspring and more importantly, psychological maturity. The children who can affect their future family relationships. In this case, reducing the child divorce rate must be a concern. ${ }^{1}$

In 2018, 1 in 9 girls married in Indonesia. Women aged 20-24 years who married before the age of 18 in 2018 are estimated to reach around 1,220,900 and this figure places Indonesia in the 10 countries with the highest absolute number of child marriages in the world. ${ }^{2}$ Underage marriage or what is commonly referred to as early marriage is increasingly prevalent among Indonesian teenagers. The number of early marriages in Indonesia is relatively high, around $20 \%$ of the total

\footnotetext{
${ }^{1}$ Abdul Mutalip and Rozihan, "Married Dispensation in Pressing Efforts of Divorce Numbers", Law $\begin{array}{llllll}\text { Development Journal } & \text { Vol. } & 3 & \text { No. } & 3 & \text { (2020), }\end{array}$ http://jurnal.unissula.ac.id/index.php/ldj/article/view/11800/4971

2 Unicef Indonesia, BPS, PUSKAPA UI, Badan Pusat Statistik, 2020, Pencegahan Perkawinan Anak: Percepatan yang Tidak Bisa Ditunda, https://www.unicef.org/indonesia/id/laporan/perkawinananak-di-indonesia
} 
number of marriages each year are marriages carried out by couples who are less than 19 years old. ${ }^{3}$

This fact is of course very worrying for the younger generation, especially for their growth and development as well as eliminating the basic rights they should have, such as the right to education, health rights, civil rights, the right to be free from discrimination and violence and other rights. The state must be able to guarantee efforts to protect children from the practice of underage marriage. Whereas according to the Ius Constitutum, in fact the government through the Child Protection Act has regulated that every parent is responsible and obliged to prevent marriage at the age of children. ${ }^{4}$

In Indonesia, guarantees for children's rights are stated in the 1945 Constitution which states that every child has the right to survive, grow and develop, and is entitled to protection from violence and discrimination. ${ }^{5}$ The guarantee for children's rights was then reaffirmed through the issuance of Act No. 23 of 2002 concerning Child Protection which has now been changed to Act No. 35 of 2014 concerning Child Protection which defines a child as someone who is not yet 18 years old. Regarding child marriage, Act No. 35 of 2014 explicitly mentions the obligations of parents in preventing child marriage. ${ }^{6}$ The Government of Indonesia's commitment to preventing child marriage was later realized with the issuance of Act No. 16 of 2019 which amended Article 7 regarding the minimum age for child marriage in Act No. 1 of 1974 concerning Marriage. With the issuance of Act No. 16 of 2019 the minimum age for marriage for women has increased from 16 years to 19 years.

According to the legislators, so that marriages do not end in divorce, marriages between prospective husbands and wives who are underage must be prevented, because marriage has a relationship with population problems, so to limit the higher birth rate, marriages must be prevented between prospective husbands and underage wife. ${ }^{7}$

Various policies at the global and national levels are a good sign that the stakeholders, especially the Government of Indonesia are committed to preventing the practice of child marriage. This policy needs to be supported by an adequate strategy by reflecting on the current situation of child marriage practices, and adopting an approach that has proven successful in preventing and responding to the practice of child marriage in Indonesia.

The Supreme Court also made Supreme Court Regulation (Perma) Number 5 of 2019 for Marriage Dispensation. It is hoped that this will tighten the requirements for child marriage and support a process that takes into account the

\footnotetext{
${ }^{3}$ Samsul Arifin, Akhmad Khisni, dan Munsharif Abdul Chalim, "The Limit of Age of Marriage Is Related to The Certification of Marriage", Jurnal Daulat Hukum Vol. 3 No. 2 (2020), http://jurnal.unissula.ac.id/index.php/RH/article/view/10084/4157

4 Act No. 35 of 2014 concerning Amendments to Act No. 23 of 2002 concerning Child Protection Article 26 paragraph (1)

${ }^{5}$ Article 28 B paragraph (2) of the 1945 Constitution

${ }^{6}$ Article 16 paragraph (1) letter c of Act No. 35 of 2014 concerning Child Protection

${ }^{7}$ Rifki Julian Wiranda and Akhmad Khisni, "Pro-Contra of Marriage Age Restriction In Maqashid Syari'ah Perspective", Law Development Journal Vol. 3 No. 3 (2021), http://jurnal.unissula.ac.id/index.php/ldj/article/view/16211/5933
} 
best interests of the child. The DPR's decision to increase the minimum age also tightened dispensation regulations and required the Religious or General Courts to first hear both parties to the marriage.

Departing from the explanation above, the researcher is interested and intends to do research which aims to know the effectiveness of the regulation on the marriage age limit based on Act No. 16 of 2019 at the Jepara Religious Court.

\section{Research Methods}

The method used in this research is juridical-sociological. The juridical approach will discuss research using laws relating to the regulation of the marriage age limit and marriage dispensation, which is contained in Act No. 1 of 1974, Constitution Number 16 of 2019, the Compilation of Islamic Law, and others. Sociological approach, this approach is used to find out and analyze the judge's view of the case for a marriage dispensation application at the Jepara Religious Court.

\section{Results and Discussion}

Actually reflects discrimination and the elimination of basic rights and neglect of women's mental and physical health. The increasingly advanced era encourages women to do all forms of productivity and achieve proper education. Women have the same basic rights as men such as education, social rights, civil rights, economic rights and other constitutional rights as citizens. ${ }^{8}$

The Jepara Religious Court noted an increase in the number of submissions marriage dispensation from 2016 to August 2021, this increase was proposed by brides under the age of 19. In 2016 there were 125 cases, in 2017 there were 114 cases, in 2018 there were 117 cases, in 2019 there were 188 cases increased. Whereas in 2020 there were 423 cases of marriage dispensation, even in 2021 from January to August (not yet the end of the year), there were 360 cases. $^{9}$

The highest number of applicants for marriage dispensation are prospective brides in the age range of 17-18 years. This is due to the provisions of the marriage age limit after the promulgation of Act No. 16 of 2019, which was originally the minimum marriage age limit of 16 years for women and 19 years for men, then changed to 19 years for men and women. ${ }^{10}$

Legal effectiveness is a legal ability to create or create conditions or situations desired by law or expected by law. ${ }^{11}$ Law can be said to be effective if there is a positive legal impact, at that time the law reaches its target in guiding or changing human behavior so that it becomes legal behavior. ${ }^{12}$ According to

\footnotetext{
${ }^{8}$ Moch Nurcholis, "Penyamaan Batas Usia perkawinan pria dan wanita perspektif Maqasid al-Usrah (Analisis Putusan Mahkamah Konstitusi Nomor 22/PUU-XV/2017),” Jurnal Mahakim Vol. 3 No. 1 January 2019, https://jurnal.iainkediri.ac.id/index.php/mahakim/article/view/1328/725

${ }^{9}$ First Level Case Reports Received at the Jepara Religious Court 2016 to August 2021

${ }^{10}$ Interview with Rosidi, Junior Registrar of Laws at the Jepara Religious Court.

11 W. Yudho and H. Tjandrasari, 1987, Efektivitas Hukum dalam Masyarakat, Majalah Hukum dan, Sosiologi Hukum, Jakarta: Sinar Grafika, p. 59

${ }^{12}$ Soerjono Soekanto, 1988, Efektivitas Hukum dan Penerapan Sanksi, CV. Ramadja Karya, Bandung, p. 80.
} 
Soerjono Soekanto that the effectiveness of a law is determined by 5 (five) factors, namely ${ }^{13}$ :

- The legal factor itself (law).

- Law enforcement factors.

- Factor facilities or facilities.

- Community factors.

- Cultural factors. ${ }^{14}$

Based on this, if it is associated with a legal product, in this case the Law of the Republic of Indonesia Number 16 of 2019 concerning Amendments to Act No. 1 of 1974 concerning Marriage, in order to realize its objectives, the ineffective implementation of the Law of the Republic of Indonesia Number 16 of 2019 Regarding the Amendment to Act No. 1 of 1974 concerning Marriage, it is caused by the following factors:

\section{Legal or statutory factors.}

Based on the theories of legal science, three kinds of things can be distinguished regarding the enactment of the law as a rule, namely:

- The law applies juridically, if the determination is based on a higher level rule or is formed on a predetermined basis.

- The law applies sociologically, if the rule is effective. That is, the rules in question can be enforced by the authorities even though they are not accepted by the community or the rules apply because of recognition from the community.

- The law applies philosophically, that is, in accordance with the ideals of the law as the highest positive value.

If the law is studied in depth, in order for the law to function, every rule of law must fulfill juridical, sociological and philosophical elements, because if the rule of law only applies juridically, there is a possibility that the rule is a dead rule, if it only applies sociologically in the meaning of the theory of power, then the rule becomes a coercive rule, if it only applies philosophically, it is possible that the rule is only the law that is aspired to. ${ }^{15}$

In this case, what is meant by law is in a material sense, namely written regulations that are generally accepted and made by legitimate central and regional authorities. The age of marriage has been clearly stipulated in the Marriage Law. Previously, the age limit for marriage in Act No. 1 of 1974 was 16 years for women and 19 years for men. Then it was changed and equalized to 19 years for both men and women through Act No. 16 of 2019.

The regulations regarding the minimum age for marriage are clear, but there is Article 7 paragraph 2 Act No. 16 of 2019 which still provides an opportunity for the existence of a situation that is an exception. "In the event that there is a

\footnotetext{
13 Chuasanga A., Ong Argo Victoria. (2019). Legal Principles Under Criminal Law in Indonesia and $\begin{array}{llllll}\text { Thailand, Jurnal Daulat Hukum, Vol } & \text { 2, } & \text { No } & 1 & \text { (2019) }\end{array}$ http://jurnal.unissula.ac.id/index.php/RH/article/view/4218

${ }^{14}$ Romli Atmasasmita, (2001), Reformasi Hukum, Hak Asasi Manusia \& Penegakan Hukum, Bandung: Mandar Maju, p. 55.

15 Loc.cit
} 
deviation from the age provisions as referred to in paragraph (1), the parents of the male and/or female parents may request a dispensation from the Court for reasons of great urgency accompanied by sufficient supporting evidence." Legislation that provides opportunities with the rules of the permit for dispensation that should contradict the age limit for marriage.

Based on case reports at the Jepara Religious Court and interviews with several Jepara Religious Court judges, there is a fact that the high number of marriage dispensations at the Jepara Religious Court, shows that there are still many practices of marriage at a young age that occur in Jepara.

The law itself has provided an exception to the limitation on the age of marriage. However, there is Article 7 paragraph 1Act No. 16 Years 2019remains a priority. Because if you make an exception in paragraph 2 , then the consequence is that you must first apply for a marriage dispensation to the court.

\section{Law enforcement factors.}

The scope of the term "law enforcement" is very broad, including those who are directly and indirectly involved in the field of law enforcement. In this case, what is meant by law enforcement will be limited to those who are directly involved in the field of law enforcement which includes not only law enforcement, but also peace maintenance. Includes those who serve in the fields of justice, prosecutors, police, law, and correctional facilities. ${ }^{16}$ In this study, what is meant by law enforcement is the judges at the Jepara Religious Court.

One key to success in law enforcement is the mentality or personality of law enforcement. The function of law enforcement here is a function in the context of implementing the Law of the Republic of Indonesia Number 16 of 2019 and participating in realizing the objectives of the law.

Based on the researcher's interview with one of the judges that the new marriage age limit regulation (Act No. 16 of 2019) actually resulted in more promiscuity and cohabitation for young couples, even though according to Islam, marriage must be hastened. The view of judges as law enforcers like this cannot realize the purpose of Act No. 16 of 2019 which is one of the efforts to prevent underage marriages.

Act No. 16 of 2019 and Regulation of the Supreme Court of the Republic of Indonesia Number 5 of 2019 concerning Guidelines for Adjudicating Applications for Marriage Dispensation, as a new legal product and practically cannot ensure that marriage dispensations can reduce the divorce rate, and can even increase the divorce rate, due to conditions mentally and psychologically unstable children in building a household. But of course this can be resolved with the hope that the age limit for marriage can be increased in accordance with the recently added revision of the Marriage Law. On the other hand, if in the process of examining a marriage dispensation case it is carried out carelessly, it will increase the divorce rate. So in principle, the granting of a marriage dispensation must be done carefully with various factors that must be considered noticed. ${ }^{17}$

${ }^{16}$ Soerjono Soekanto, Op.cit., p. 19.

${ }^{17}$ Abdul Mutalip and Rozihan, Op.cit. 
Factor facilities or facilities.

Without certain facilities or facilities, it is impossible for law enforcement to take place smoothly. These facilities or facilities include good organization, adequate equipment, sufficient finances, and so on. If these things are not met, it is impossible for law enforcement to achieve its objectives. ${ }^{18}$

Included in the means and facilities in supporting the effectiveness of the implementation of Act No. 16 of 2019 are good organizations and educated and skilled human resources. The smallest organization in society is the family. The nuclear family (father, mother, children) has the most important role. The functions of the nuclear family, which is the smallest unit in society, are a place where children are educated to understand and adhere to the rules and values prevailing in society, as a unit that regulates proper sexual relations, as a socioeconomic unit that forms the basis for socio-economic life for children, as a place of shelter, so that life takes place in an orderly and peaceful manner. So that people live in peace. ${ }^{19}$

The role of parents today has decreased. Supervision and direction of parents on the association of young people is very necessary. In the case of the application for dispensation from marriage, the Petitioner as a parent uses the reason "worried about adultery or further intercourse...", this will not happen if the parents are fully responsible for controlling and directing their child until the child is an adult and is materially and physically ready emotional to get married.

Apart from parents, what is included in the facilities and facilities is the presence of technology. Technology is now very advanced. The existence of the internet can already be consumed by most of the people of Indonesia. This should be a tool to find out information and provide information about the consequences of promiscuity, the consequences of free sex, and the effects of underage marriage.

\section{Community factors.}

One factor that makes a regulation effective is the community. What is meant here is public awareness to comply with a statutory regulation, which can also be called the degree of compliance. The degree of compliance can only be measured if there is public knowledge of the law. If a statutory regulation has been promulgated and issued according to a legal and official procedure, then legally the statutory regulation applies.

To community compliance as one of the factors causing the effectiveness of the law. In research conducted by researchers, that the increase in the regulation on the minimum age limit for women to marry was raised in Act No. 16 of 2019 which is not effective for the people of Jepara Regency. This is shown by the increase in applications for marriage dispensation at the Jepara Religious Court after the birth of Act No. 16 of 2019 the number of applications for marriage dispensation has increased very significantly, 2 times more than before the birth of Act No. 16 of 2019.

\footnotetext{
${ }^{18}$ Soerjono Soekanto, (2008), Faktor-Faktor yang Mempengaruhi Penegakan Hukum, Jakarta: PT. Raja Grafindo Persada, p. 80

${ }^{19}$ Soerjono Soekanto, (2004), Sosiologi Keluarga (Tentang Ikhwal Keluarga, Remaja dan anak), Third Print., Jakarta: PT. Rineka Cipta, p. 85
} 


\section{Cultural factors.}

Culture is defined as the result of work, creativity and taste based on human initiative in social life. Indonesia is a country with a pluralistic society. No wonder the culture in Indonesia is also diverse. Plurality is seen mainly from tribes, each of which has a special culture. That doesn't mean there are no similarities at all. However, the differences that appear, because of the possibility of a collision, actually stem from inequality.

The five factors above are closely related to each other, therefore they are the essence of law enforcement, also a measure of the effectiveness of law enforcement, which determines whether the written law can function properly or not depends on the law itself. In addition, it must also be considered carefully in the law enforcement process. Because if you don't get enough attention, then law enforcement will not be achieved.

\section{Clossing}

Based on the analysis of the theory of legal effectiveness, the regulation on the minimum age limit for women to marry was raised in Act No. 16 of 2019 which is not effective for the people of Jepara Regency. This is shown by the increase in applications for marriage dispensation at the Jepara Religious Court after the birth of Act No. 16 of 2019 the number of applications for marriage dispensation has increased very significantly, 2 times more than before the birth of Act No. 16 of 2019.

\section{References}

\section{Journals:}

[1] Abdul Mutalip and Rozihan, "Married Dispensation in Pressing Efforts of Divorce Numbers", Law Development Journal Vol. 3 No. 3 (2020), http://jurnal.unissula.ac.id/index.php/ldj/article/view/11800/4971

[2] Chuasanga A., Ong Argo Victoria, "Legal Principles Under Criminal Law in Indonesia and Thailand", Jurnal Daulat Hukum, Vol 2, No 1 (2019) http://jurnal.unissula.ac.id/index.php/RH/article/view/4218

[3] Moch Nurcholis, "Penyamaan Batas Usia perkawinan pria dan wanita perspektif Maqasid al-Usrah (Analisis Putusan Mahkamah Konstitusi Nomor 22/PUU-XV/2017)," Jurnal Mahakim Vol. 3 No. 1 January 2019, https://jurnal.iainkediri.ac.id/index.php/mahakim/article/view/1328/725

[4] Rifki Julian Wiranda and Akhmad Khisni, "Pro-Contra of Marriage Age Restriction In Maqashid Syari'ah Perspective”, Law Development Journal $\begin{array}{lllll}\text { Vol. } & 3 & \text { No. } & & \text { (2021), }\end{array}$ http://jurnal.unissula.ac.id/index.php/ldj/article/view/16211/5933

[5] Samsul Arifin, Akhmad Khisni, dan Munsharif Abdul Chalim, "The Limit of Age of Marriage Is Related to The Certification of Marriage", Jurnal Daulat $\begin{array}{llllll}\text { Hukum Vol. } & 3 & \text { No. } & 2 & \text { (2020), }\end{array}$ http://jurnal.unissula.ac.id/index.php/RH/article/view/10084/4157

\section{Books:}


[1] Romli Atmasasmita, 2001, Reformasi Hukum, Hak Asasi Manusia \& Penegakan Hukum, Bandung: Mandar Maju

[2] Soerjono Soekanto, 2004, Sosiologi Keluarga (Tentang Ikhwal Keluarga, Remaja dan anak), Third Print., Jakarta: PT. Rineka Cipta

[3] Soerjono Soekanto, 2008, Faktor-Faktor yang Mempengaruhi Penegakan Hukum, Jakarta: PT. Raja Grafindo Persada

[4] Soerjono Soekanto, 1988, Efektivitas Hukum dan Penerapan Sanksi, CV. Ramadja Karya, Bandung

[5] W. Yudho and H. Tjandrasari, 1987, Efektivitas Hukum dalam Masyarakat, Majalah Hukum dan), Sosiologi Hukum, Jakarta: Sinar Grafika

\section{Regulation:}

[1] Act No. 35 of 2014 concerning Amendments to Act No. 23 of 2002 concerning Child Protection

[2] Act No. 35 of 2014 concerning Child Protection

[3] Constitutionof 1945

\section{Interview:}

[1] Interview with Rosidi, Junior Registrar of Laws at the Jepara Religious Court.

[2] Interview with Jepara Religious Court Judge on August 16, 2021

\section{Internet:}

[1] Unicef Indonesia, BPS, PUSKAPA UI, Badan Pusat Statistik, 2020, Pencegahan Perkawinan Anak: Percepatan yang Tidak Bisa Ditunda, https://www.unicef.org/indonesia/id/laporan/perkawinan-anak-diindonesia 